\title{
ODONTOMAS: PEDIATRIC CASE REPORT AND REVIEW OF THE LITERATURE
}

\author{
Tomislav Ćabov ${ }^{1}$, Petra Nola Fuchs ${ }^{1,3}$, Ana Zulijani ${ }^{2}$, \\ Lucija Ćabov Ercegović ${ }^{3}$ and Srđan Marelić ${ }^{4}$ \\ ${ }^{1}$ Department of Oral Surgery, University of Rijeka, Faculty of Dental Medicine, Rijeka, Croatia; \\ ${ }^{2}$ Department of Oral Surgery, Rijeka University Hospital Centre, Rijeka, Croatia; \\ ${ }^{3}$ Zagreb Dental Polyclinic, Zagreb, Croatia; \\ ${ }^{4}$ Private Orthodontic Practice, Rijeka, Croatia
}

\begin{abstract}
SUMMARY - Odontomas are benign odontogenic tumors formed from epithelial and mesenchymal cells. They are mostly associated with disorders of tooth eruption, causing impaction and/or delayed tooth eruption, and are an accidental finding on routine radiological examination. The aim of this paper is to present current findings in the etiology and treatment of odontomas, as well as the clinical and radiographic features, describing a case that is rarely found in the literature. A case of multiple complex odontoma in the mandible of an 11-year-old boy is presented, causing impaction of the first permanent right molar, 46. The treatment consisted of surgical enucleation of the multiple complex odontoma with preservation of the impacted tooth, monitoring clinically and radiologically its spontaneous eruption followed by final orthodontic alignment. Odontomas are not an everyday part of clinical practice and given that they are most commonly associated with permanent tooth impaction, it is extremely important to have knowledge of their clinical and radiological features. Early diagnostics and appropriate treatment result in better diagnosis, thus increasing the possibility of preserving the impacted teeth.
\end{abstract}

Key words: Odontogenic tumors; Odontoma; Tooth, impacted; Pediatric dentistry

\section{Introduction}

The term 'odontoma' was first introduced by Paul Broca in 1867 and was originally used for any tumor and/or tumor-like lesion of odontogenic origin ${ }^{1}$. Over years, as a consequence of new insights, the term odontoma has changed its meaning, and since 2017 it has been classified according to the World Health Organization (WHO) in a group of benign mixed epithelial and mesenchymal odontogenic tumors ${ }^{2}$. However, it is defined as tumor-like malformations (hamartomas) consisting of hard and soft dental tissues, enamel and dentine with different proportions of pulp and cement,

Correspondence to: Ana Zulijani, DMD, Department of Oral Surgery, Rijeka University Hospital Centre, Krešimirova 40, HR51000 Rijeka, Croatia

E-mail: ana.zulijani@gmail.com

Received January 18, 2021, accepted February 24, 2021 not representing a true neoplasm ${ }^{1-5}$. The incidence of odontogenic tumors ranges from $0.002 \%$ to $0.1 \%$, with odontomas being the most common odontogenic tumors $(20 \%-67 \%)$, most commonly diagnosed in the first two decades of life regardless of gender ${ }^{2,4,6-9}$. The etiology of odontoma is poorly known, although some studies have identified local trauma, inflammatory processes, and chronic infections during odontogenesis as possible factors. Other possible factors include genetic background, such as odontoblastic hyperactivity, or hereditary syndromes such as Gardner's syndrome and Hermann's syndrome $e^{1-3,8,10}$. According to many studies, odontomas generally do not cause subjective disturbances, but often cause interference in tooth eruption, and are diagnosed accidentally through routine radiological examinations as a radiopaque zone separated by a radiolucent zone from the surrounding bone $e^{2,6,8,9}$. 
The WHO divides odontomas into complex $(\mathrm{CxOD})$ and compound ( $\mathrm{CpOD})$ odontomas, given the organization and degree of differentiation of odontogenic cells ${ }^{2-4,6-8}$. Complex odontoma consists of calcified dental tissue less differentiated than normal dental tissue, and makes an amorphous mass separated by connective tissue from the surrounding bone. Compound odontoma consists of a large number of dental structures that resemble normal dental tissue, only in a smaller dimension, many tooth rudiments separated by connective tissue that at the same time separates the entire structure from the surrounding bone ${ }^{2}$. They can

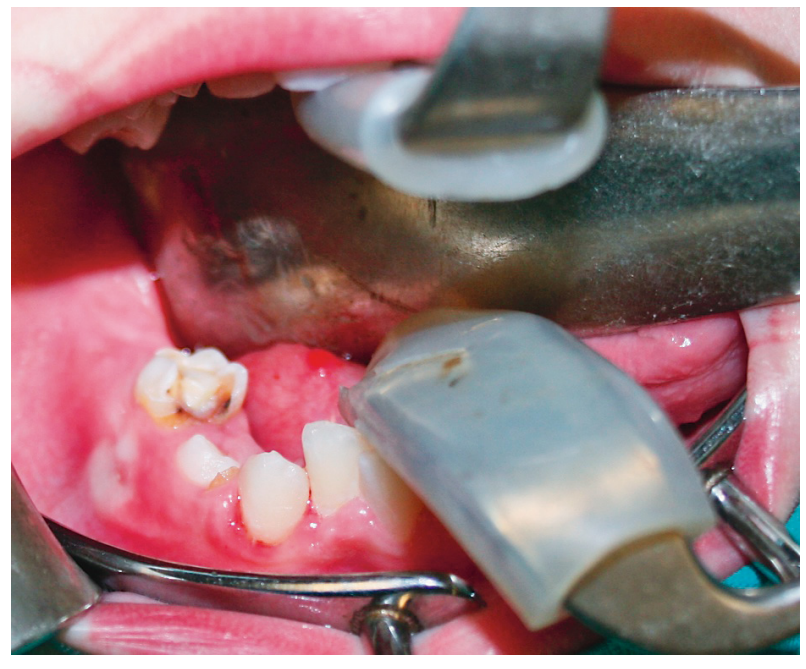

Fig. 1. Intraoral photograph before the surgery. occur in any area, however, compound odontomas are mostly located in the anterior maxilla $(81.8 \%)$, whereas complex odontomas are most commonly located in the posterior mandible (63\%) and in the anterior maxilla $(16 \%)^{2,4}$. Therapy of choice is surgical removal of the entire odontoma with a low likelihood of recurrence $^{2}$.

\section{Case Report}

An 11-year-old boy presented to the Department of Oral Surgery, Rijeka University Hospital Centre, referred by an orthodontist for an unknown amorphous mass visible on the orthopantomogram in the mandible that was causing impaction of the first right permanent molar. Patient medical history excluded trauma or infection, with no family history of odontoma.

Extraoral examination revealed no facial asymmetry. Intraoral clinical examination revealed a stage of mixed dentition with decayed deciduous teeth and absence of the first right mandibular permanent molar, 46. Slight expansion of the cortical bone from the vestibular and lingual side was present in the area of the first right mandibular permanent molar, with solid consistency and without symptoms (Fig. 1). On the performed orthopantomogram, a radiopaque well-defined mass was observed above the crown of the first right mandibular permanent molar, of similar intensity of calcified dental tissues, surrounded by a radiolucent

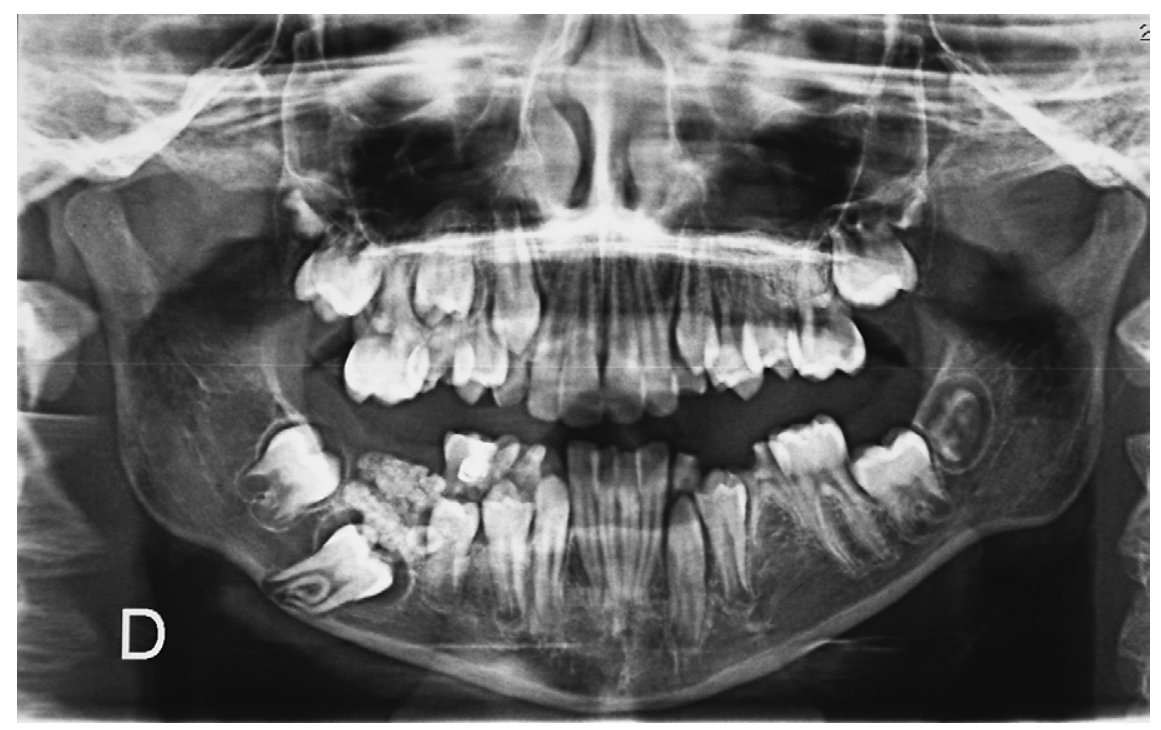

Fig. 2. Orthopantomogram showed a radiopaque mass on the right side of the mandible above the impacted 46. 

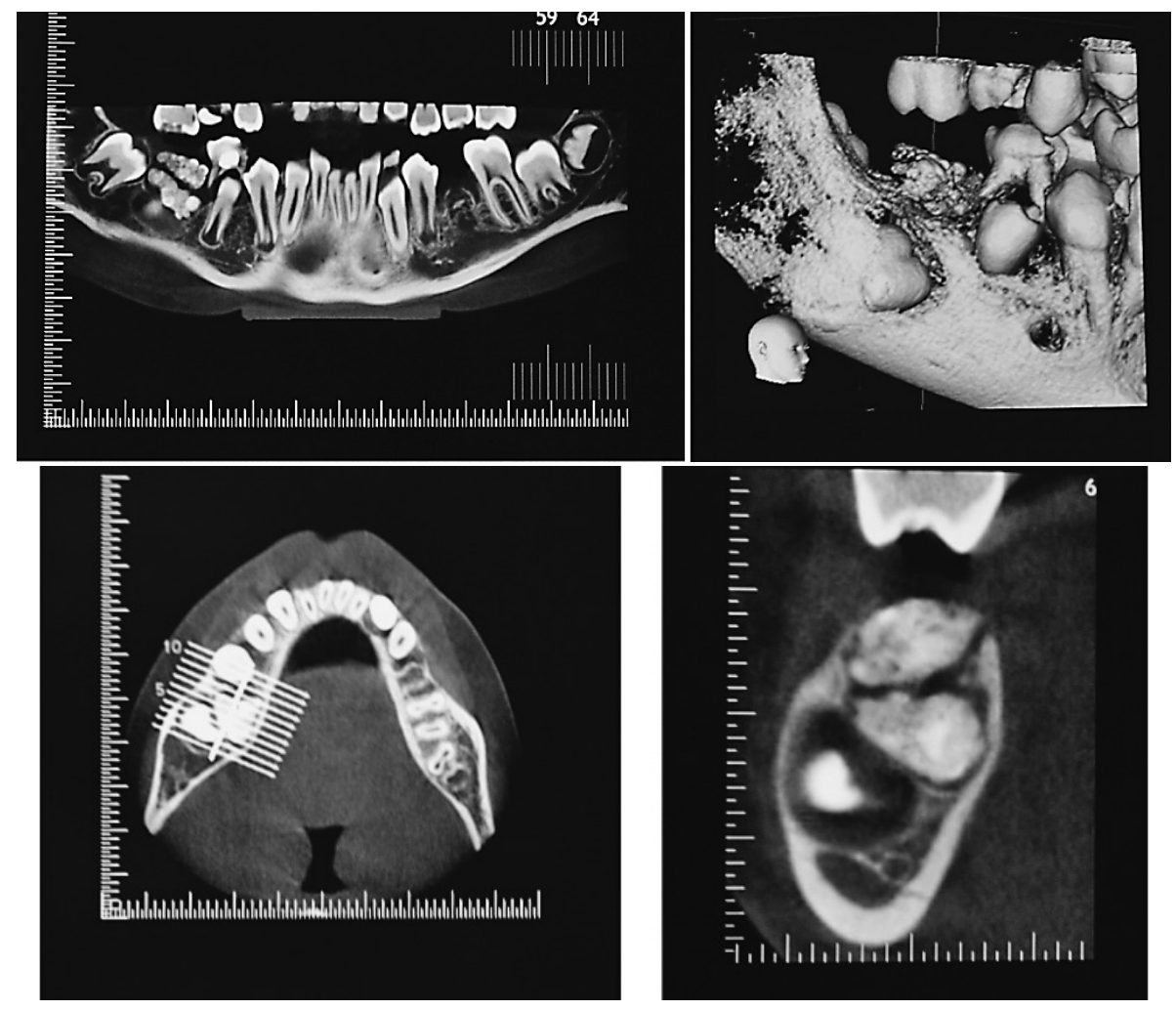

Fig. 3. CBCT scan of the posterior right mandible prior to the surgery: cross section shows two radiopaque masses located one below another and underneath them a non-erupted tooth; a thinned buccal cortical bone, two well-limited radiopaque masses.
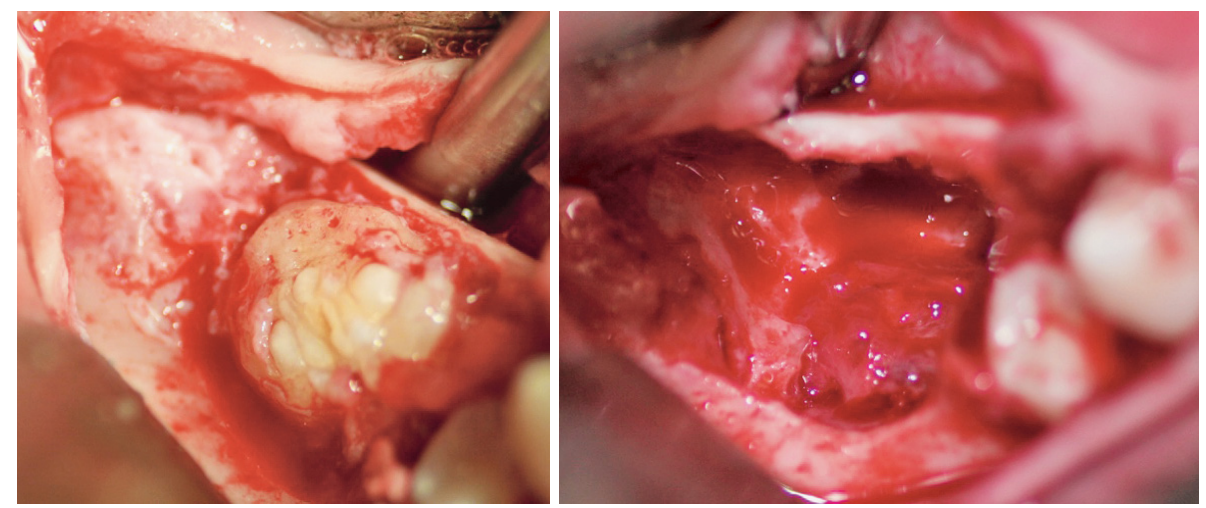

Fig. 4. Intraoral photographs of the surgery: odontoma in the region of the 46 after reflection full-thickness buccal flap (left panel); residual bone cavity after removal of the odontomas, without disturbing the impacted 46 (right panel).

zone that separated it from the surrounding bone, and hypodontia of the second left mandibular premolar, 35 (Fig. 2).

A cone beam computed tomography (CBCT) image of the lower jaw in the area of the first right man- dibular permanent molar confirmed the presence of two irregular radiopaque well-defined amorphous masses, one above another and above the tooth crown 46, measuring approximately $14 \times 12 \mathrm{~mm}$ (Fig. 3). Based on radiographic and clinical features, a provi- 
sional diagnosis of multiple complex odontomas was established. In agreement with the orthodontist, surgical procedure was planned to remove odontomas under general anesthesia, after which spontaneous erup-

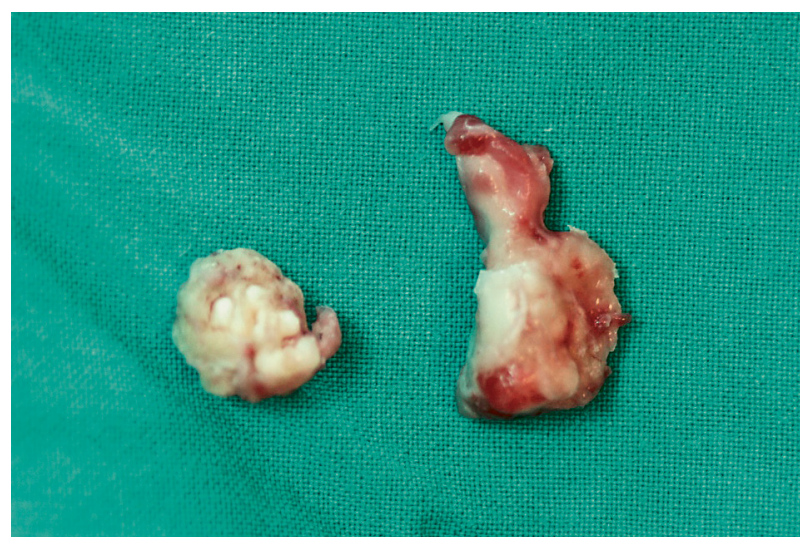

Fig. 5. Complex odontomas removed by the surgery.

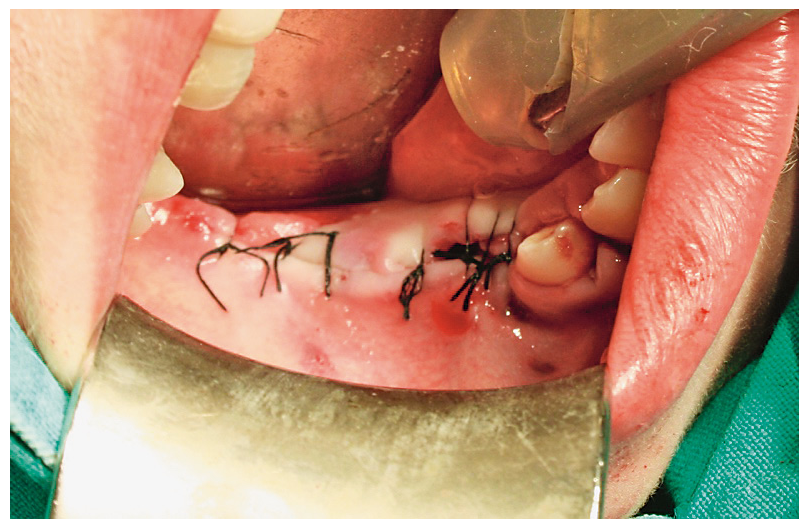

Fig. 6. Intraoral photograph after the surgery: the flap was closed with 3.0 silk sutures. tion of the impacted tooth followed. If spontaneous eruption would not occur, an orthodontic-surgical approach is a treatment option to preserve impacted permanent teeth, surgical exposure and orthodontic traction of teeth.

The surgery was carried out under general anesthesia. A full thickness buccal mucoperiosteal flap was raised and using carbide bur, with abundant irrigation of the saline solution, the thin overlying of cortical bone was removed. A clearly limited complex odontoma was exposed, circumscribed by a connective tissue capsule (Fig. 4).

The two complex odontomas were completely removed, leaving a cavity with exposure of the tooth crown of impacted tooth 46 (Fig. 5). The edges of the bone were rounded, and the wound was washed with saline and sutured with 4/0 silk (Fig. 6).

The postoperative course was uneventful. Histopathologic examination confirmed the provisional diagnosis of complex odontoma. Orthopantomogram taken six months after the surgery showed spontaneous eruption of the impacted tooth 46 (Fig. 7). The impacted tooth had been monitored clinically and radiologically until it was placed in the dental arch, followed by orthodontic treatment due to malposition of the tooth (Fig. 8).

\section{Discussion}

In this case, two complex odontomas are shown, localized above the crown of the first right mandibular permanent molar causing its impaction. Complex odontomas are most commonly found in lower jaws in

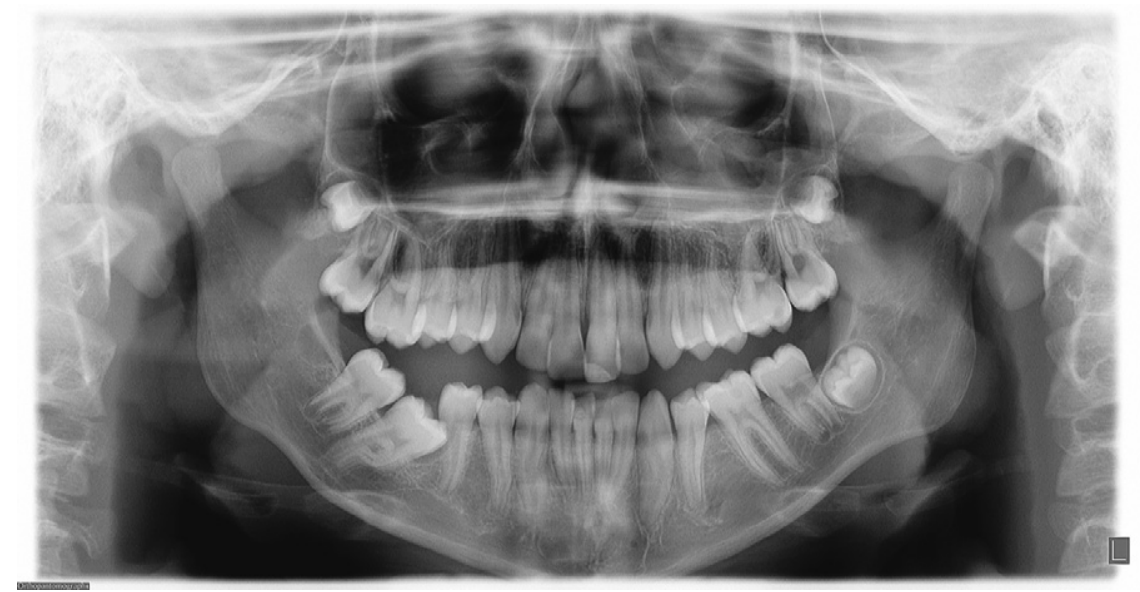

Fig. 7. Orthopantomogram taken six months after the surgery. 


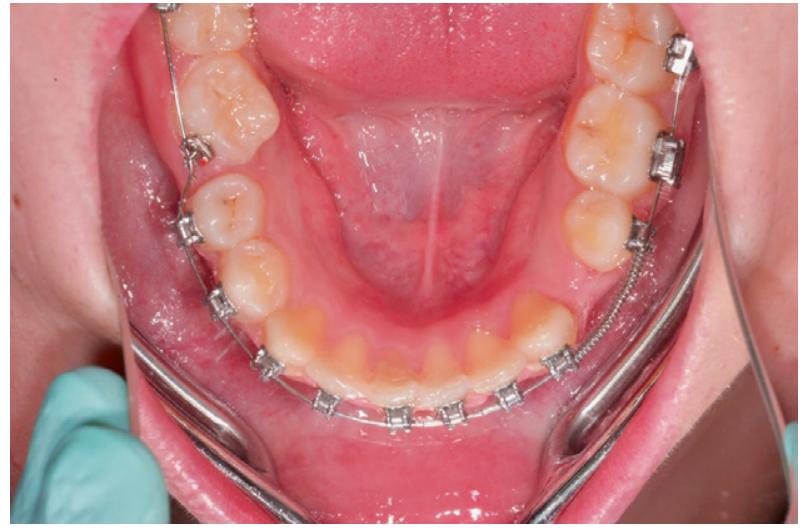

Fig. 8. Occlusal views during orthodontic treatment.

the area of the second and third molars ${ }^{8}$. In the literature, cases of multiple complex odontomas have been rarely reported ${ }^{10}$. Odontomas, as in this case, are most commonly diagnosed on radiography examination taken to determine the cause of missing or malposition of an individual tooth, more frequently in permanent dentition than in deciduous dentition ${ }^{1,6,9,11-13}$. For the same reason, it is recommended for them to be removed early in order to allow proper spontaneous eruption of teeth in dental arch. The treatment of odontoma is surgical and may be associated with orthodontic therapy, i.e. malocclusion correction or orthodontic traction of an impacted tooth caused by the presence of odontoma ${ }^{7,14}$. In the case presented, surgical removal of the odontoma was indicated, as well as monitoring of spontaneous eruption of the affected tooth.

Odontomas are the most common odontogenic tumors, and according to the WHO, two types can be distinguished, complex and compound odontomas. Some studies describe another type of odontoma, mixed odontomas, as a combination of the characteristics of compound and complex odontomas ${ }^{8,15}$. Compound odontomas are more commonly diagnosed in the population than complex odontomas, at a 2:1 ratio, although some studies have reported an equal prevalence ${ }^{7,8,13,16}$. They are mostly diagnosed accidentally in the second decade of life, with a peak around 14 years of age $\mathrm{e}^{5-7}$. Odontomas are mostly asymptomatic, usually associated with delayed eruption of teeth or impacted tooth, and may later cause swelling, cortical bone enlargement, or pain. They are characterized by slow and limited growth, meaning that they grow until the moment when dental tissue has completed its develop- ment, so they usually do not exceed 10 to $20 \mathrm{~mm}$ in size $^{6-8,17}$. In the literature, some cases of extremely large odontomas that caused cortical bone expansion and consequently facial asymmetry are described ${ }^{3,17-20}$. The most common localization of odontoma is the anterior part of the jaws ${ }^{4,6,13}$.

Clinically, they can be divided into intraosseous and extraosseous odontomas, and according to some studies, central and peripheral odontomas, that is, odontomas located within the bone and odontomas located within the soft tissue ${ }^{10,21}$. Intraosseous odontomas can rarely erupt into the oral cavity over time, whereas extraosseous odontomas are a very rare entity and tend to break out inside the oral cavity. Erupted odontoma is a third variety of odontomas in clinical classification $^{1,3}$. In the literature, several cases of erupted odontoma into the oral cavity have been reported, most commonly associated with pain and infection of the surrounding mucosa $\mathrm{a}^{8,18,19,21,22}$.

Radiological odontomas can be divided by development stages based on calcification. Completely radiolucent odontomas, that is, the absence of mineralization is really described in the literature. The second stage is characterized by partial calcification; and in the final development stage, mature odontomas are mostly a compound of calcified dental tissue surrounded by radiolucent zone $\mathrm{e}^{10,11,14}$.

The treatment of odontoma includes surgical removal of the lesion with a small percentage of recurrence, which occurs in case of incomplete enucleation $^{2,5-7,11}$. The case presented had no recurrence. In the literature, two-stage surgical management is described for large odontomas where the risks of pathologic fracture and damage to vital anatomic structures are higher ${ }^{10,15,23,24}$. Since odontomas are in most cases an obstacle to the emergence of permanent teeth, causing permanent tooth impaction, there is no general agreement for the treatment of an impacted tooth in the literature. The possible options include extracting the impacted tooth, surgical repositioning, surgical exposure of the impacted tooth with or without orthodontic tooth extraction, and clinical and radiological monitoring of the impacted tooth until its spontaneous eruption ${ }^{14}$. There are several clinical investigations focused on the diagnosis of impacted teeth. The success rate of preservation ranges from $45 \%$ to $75.8 \%$ with or without surgical exposure of the crown and orthodontic traction of the affected teeth, depending 
on the study ${ }^{8,11,14}$. Spontaneous eruption has been described in a small number of cases ${ }^{11,12}$. In the study by Tomizawa et al., the impacted teeth erupted spontaneously after surgical removal of odontomas in 8 of 25 cases $^{11}$. In general, if apexogenesis is not completed, spontaneous tooth eruption is expected, otherwise, there is no potential for eruption ${ }^{25}$. Successful preservation of the impacted tooth with increasing age is reduced, as well as the possibility of spontaneous eruption ${ }^{14}$. The possibility of setting up an impacted tooth in the dental arch supports the efforts made to preserve the impacted teeth during the procedure. Morning reports on eruption of the impacted teeth associated with odontomas in about $75 \%$ of cases, with surgical and/or orthodontic intervention ${ }^{26}$. Likewise, early diagnosis of odontoma increases the success of preserving the impacted tooth caused by odonto$\mathrm{ma}^{8,11,14}$.

During surgery, it is necessary to be careful not to damage the impacted tooth, adjacent teeth, and anatomic structures of the jaw. Therefore, it is important to accurately localize the odontoma preoperatively by radiography and to determine its relationship with the adjacent structures. CBCT is a radiographic technique that can help in the evaluation of localization and spatial relationship of odontomas, but it is not indicated on a regular basis in spite of much less radiation than $\mathrm{CT}^{12,15,17,27}$.

\section{Conclusion}

Odontomas are not an everyday part of clinical practice and given that they are most commonly associated with permanent tooth impaction, it is extremely important to have knowledge of their clinical and radiological features. Early diagnostics and appropriate treatment result in better diagnosis, thus increasing the possibility of preserving the impacted teeth.

\section{References}

1. Satish V, Prabhadevi MC, Sharma R. Odontome: a brief overview. Int J Clin Pediatr Dent. 2011;4(3):177-85. doi: 10.5005/ jp-journals-10005-1106

2. EI-Naggar AK, Chan JKC, Grandis JR, Takata T, Slootweg PJ. WHO Classification of Head and Neck Tumours: Odontogenic and Maxillofacial Bone Tumours. IARC: Lyon, 2017; p. 224-6.
3. Akerzoul N, Chbicheb S, El Wady W. Giant complex odontoma of mandible: a spectacular case report. Open Dent J. 2017;11:413-9. doi: 10.2174/1874210601711010413

4. Siriwardena BSMS, Crane H, O'Neill N, et al. Odontogenic tumors and lesions treated in a single specialist oral and maxillofacial pathology unit in the United Kingdom in 1992-2016. Oral Surg Oral Med Oral Pathol Oral Radiol.2019;127(2):15166. doi: 10.1016/j.oooo.2018.09.011

5. Neville BW, Douglas DD, Cal MA, Angela CC. Oral and Maxillofacial Pathology: Odontogenic Cysts and Tumors. St. Louis, USA: Elsevier, 2016; p. 674-5.

6. Levi-Duque F, Ardila CM. Association between odontoma size, age and gender: multivariate analysis of retrospective data. J Clin Exp Dent. 2019;11(8):e701-6. doi: 10.4317/jced.55733

7. Boffano P, Zavattero E, Roccia F, Gallesio C. Complex and compound odontomas. J Craniofac Surg. 2012;23(3):685-8. doi: 10.1097/SCS.0b013e31824dba1f

8. Kämmerer PW, Schneider D, Schiegnitz E, et al. Clinical parameter of odontoma with special emphasis on treatment of impacted teeth - a retrospective multicentre study and literature review. Clin Oral Investig. 2016;20(7):1827-35. doi: 10.1007/s00784-015-1673-3

9. Troeltzsch M, Liedtke J, Troeltzsch V, Frankenberger R, Steiner T, Troeltzsch M. Odontoma-associated tooth impaction: accurate diagnosis with simple methods? Case report and literature review. J Oral Maxillofac Surg. 2012;70(10):e516-20. doi: 10.1016/j.joms.2012.05.030

10. Sun L, Sun Z, Ma X. Multiple complex odontoma of the maxilla and the mandible. Oral Surg Oral Med Oral Pathol Oral Radiol. 2015;120(1):e11-6. doi: 10.1016/j.oooo.2015.02.488

11. Tomizawa M, Otsuka Y, Noda T. Clinical observations of odontomas in Japanese children: 39 cases including one recurrent case. Int J Paediatr Dent. 2005;15(1):37-43. doi: 10.1111 j.1365-263X.2005.00607.x

12. Hisatomi M, Asaumi JI, Konouchi H, Honda Y, Wakasa T, Kishi K. A case of complex odontoma associated with an impacted lower deciduous second molar and analysis of the 107 odontomas. Oral Dis. 2002;8(2):100-5. doi: 10.1034/j.16010825.2002.1c778.x

13. Hidalgo-Sánchez O, Leco-Berrocal MI, Martínez-González JM. Metaanalysis of the epidemiology and clinical manifestations of odontomas. Med Oral Patol Oral Cir Bucal. 2008; 13(11):E730-4.

14. An SY, An CH, Choi KS. Odontoma: a retrospective study of 73 cases. Imaging Sci Dent. 2012;42(2):77-81. doi: 10.5624/ isd.2012.42.2.77

15. Chrcanovic BR, Jaeger F, Freire-Maia B. Two-stage surgical removal of large complex odontoma. Oral Maxillofac Surg. 2010;14(4):247-52. doi: 10.1007/s10006-010-0206-0

16. Cohen DM, Bhattacharyya I. Ameloblastic fibroma, ameloblastic fibro-odontoma, and odontoma. Oral Maxillofac Surg Clin North Am. 2004;16(3):375-84. doi: 10.1016/j.coms. 2004.03.005 
17. Park JC, Yang JH, Jo SY, Kim BC, Lee J, Lee W. Giant complex odontoma in the posterior mandible: a case report and literature review. Imaging Sci Dent. 2018;48(4):289-93. doi: 10.5624/isd.2018.48.4.289

18. Ali Azhar D, Kota MZ, El-Nagdy S. An unusual erupted complex composite odontoma: a rare case. Case Rep Dent. 2013; 2013:106019. doi: 10.1155/2013/106019

19. Bagewadi SB, Kukreja R, Suma GN, Yadav B, Sharma H. Unusually large erupted complex odontoma: a rare case report. Imaging Sci Dent. 2015;45(1):49-54. doi: 10.5624/isd.2015. 45.1.49

20. Cabov T, Krmpotić M, Grgurević J, Perić B, Jokić D, Manojlović S. Large complex odontoma of the left maxillary sinus. Wien Klin Wochenschr. 2005;117(21-22):780-3. doi: 10.1007/ s00508-005-0462-4

21. Junquera L, de Vicente JC, Roig P, Olay S, Rodríguez-Recio O. Intraosseous odontoma erupted into the oral cavity: an unusual pathology. Med Oral Patol Oral Cir Bucal. 2005;10(3): 248-51.
22. Hanemann JA, Oliveira DT, Garcia NG, Santos MR, Pereira AA. Peripheral compound odontoma erupting in the gingiva. Head Face Med. 2013;9:15. doi: 10.1186/1746-160X-9-15

23. Botelho J, Machado V, Gomes JC, et al. Multiple complex odontomas of the mandible: a rare case report and literature review. Contemp Clin Dent. 2019;10(1):161-5. doi: 10.4103/ ccd.ccd_463_18

24. Knezevic G, Sokler K, Knezevic AK. A two-stage surgical approach in the treatment of a large complex odontoma of the mandible. Acta Stomatol Croat. 2005;39:221-3.

25. Kokich VG, Mathews DP. Surgical and orthodontic management of impacted teeth. Dent Clin North Am. 1993;37(2): 181-204.

26. Morning P. Impacted teeth in relation to odontomas. Int J Oral Surg. 1980;9(2):81-91. doi: 10.1016/s0300-9785(80)80043-3

27. Ohman A, Kull L, Andersson J, Flygare L. Radiation doses in examination of lower third molars with computed tomography and conventional radiography. Dentomaxillofac Radiol. 2008; 37(8):445-52. doi: $10.1259 / \mathrm{dmfr} / 86360042$

Sažetak

\title{
ODONTOMI: PEDIJATRIJSKI PRIKAZ SLUČAJA I PREGLED LITERATURE
}

\author{
T. Ćabov, P. Nola Fuchs, A. Zulijani, L. Ćabov Ercegović i S. Marelić
}

Odontomi su dobroćudni odontogeni tumori nastali od epitelne i mezenhimne osnove. Najčěčé su povezani s poremećajima u nicanju zuba, uzrokujući impakciju i/ili zakašnjelo nicanje zuba te su slučajan nalaz prilikom rutinskih radioloških snimaka. Cilj ovoga rada je prikazati dosadašnja saznanja u etiologiji i liječenju odontoma, kao i kliničke i radiografske značajke, prikazujući slučaj koji se rijetko može naći u literaturi. Prikazan je slučaj višestruko složenog odontoma u mandibuli 11-godišnjaka, što uzrokuje impakciju prvog trajnog desnog kutnjaka, 46. Liječenje se sastojalo od kirurške enukleacije višestruko složenog odontoma uz očuvanje zahvaćenog zuba. Nakon operativnog zahvata klinički i radiološki se pratilo spontano nicanje impaktiranog zuba do konačnog ortodontskog ispravljanja položaja zuba. Odontomi nisu svakodnevni dio kliničke prakse, a s obzirom na to da su najčešće povezani s impakcijom trajnih zuba veoma je važno poznavati njihove kliničke i radiološke značajke. Rano dijagnosticiranje i primjereno liječenje rezultiraju boljom dijagnozom, povećavajući tako mogućnost očuvanja impaktiranih zuba.

Ključne riječi: Odontogeni tumori; Odontom; Impaktirani zub; Dječja stomatologija 